\title{
The effects of probiotic supplementation on lean body mass, strength, and power, and health indicators in resistance trained males: a pilot study
}

\author{
John Georges ${ }^{1}$, Ryan P Lowery ${ }^{1}$, George Yaman', Chris Kerio ${ }^{1}$, Jacob Ormes ${ }^{1}$, Sean A McCleary ${ }^{1}$, Matthew Sharp \\ , Kevin Shields', Jacob Rauch', Jeremy Silva ${ }^{1}$, Ned Arick', Martin Purpura ${ }^{2}$, Ralf Jäger ${ }^{2}$, Jacob M Wilson ${ }^{1 *}$
}

From The Eleventh International Society of Sports Nutrition (ISSN) Conference and Expo

Clearwater Beach, FL, USA. 20-21 June 2014

\section{Background}

While growing evidence suggests beneficial effects of probiotics on the gut-brain-axis, only a limited number of studies have investigated the impact of gut microbiota modulation on muscle physiology (gut-muscle-axis). The probiotic BC30 (Ganeden Biotech Inc., Maryfield Heights, $\mathrm{OH}$ ) has been shown to increase protein absorption and the anabolic potential of a respective protein source has been directly linked to peak plasma leucine levels. Postworkout administration of slow digesting proteins such as casein show inferior results on muscle protein synthesis in comparison to fast absorbed proteins such as whey. Thus, the purpose of this investigation was to determine if the co-administration of a probiotic with a slow digested protein has a beneficial effect on body composition, performance, and measures of perceived health.

\section{Methods}

10 healthy resistance-trained individuals volunteered to participate in this study (mean+/-SD; age: $22.0 \pm 2.4 \mathrm{yr}$; height: $181.8 \pm 4.1 \mathrm{~cm}$; weight: $85.6 \pm 12.9 \mathrm{~kg}$ ). Subjects were randomly assigned to consume either $20 \mathrm{~g}$ of casein $($ Control $=\mathrm{CON})$ or $20 \mathrm{~g}$ of casein plus probiotic $(500 \mathrm{M}$ $\mathrm{BC} 30,=\mathrm{BC} 30)$ twice daily. Subjects were instructed to consume one serving in the morning upon waking while the second serving was consumed after training or before bed on non-training days. With assistance from a dietician, macronutrients were controlled to 50\% carbohydrate, 25\% protein, and 25\% fat between groups using the Mifflin-St Jeor formula. Subjects performed full body workouts 4-times per week for 8 weeks consisting of hypertrophy

* Correspondence: jmwilson@ut.edu

${ }^{1}$ The University of Tampa, Tampa, Florida, USA

Full list of author information is available at the end of the article
(8-12 RM loads and 60 seconds rest), and strength (1-5 RM loads with 3-5 minutes rest) under supervision of the researchers in order to ensure compliance. Body composition (Dual X-Ray Absorptiometry; DXA), quadriceps thickness (ultrasound), peak power (Monark Wingate Cycle), vertical jump power (Tendo unit), 1-RM bench press, and 1-RM leg press were measured at baseline and after the eighth week of supplementation. Perceived GI health (GSRS) was measured weekly and upper respiratory health (WURSS-21) daily. Consent to publish the results was obtained from all participants.

\section{Results}

$\mathrm{BC} 30$ showed a trend $(\mathrm{p}=0.10)$ to increase vertical jump power (BC30: pre 2,136 W, post 2,262 W; CON pre $1,712 \mathrm{~W}$, post $1,691 \mathrm{~W}$ ) and might have a beneficial effect on peak power and fat mass. There were no significant differences between groups for body composition, or other performance measures. Due to an overall very low number of incidences in digestive and immune health in both groups no meaningful analysis could be done.

\section{Conclusions}

This pilot study indicated that probiotic supplementation in form of $\mathrm{BC} 30$ in combination with a slow digesting protein might increase athletic performance. However, further research with a larger $n$-size is needed to confirm these findings.

\section{Authors' details}

${ }^{1}$ The University of Tampa, Tampa, Florida, USA. ${ }^{2}$ Increnovo LLC, Milwaukee, Wisconsin, USA. 
doi:10.1186/1550-2783-11-S1-P38

Cite this article as: Georges et al:: The effects of probiotic

supplementation on lean body mass, strength, and power, and health

indicators in resistance trained males: a pilot study. Journal of the

International Society of Sports Nutrition 2014 11(Suppl 1):P38.

Submit your next manuscript to BioMed Central and take full advantage of:

- Convenient online submission

- Thorough peer review

- No space constraints or color figure charges

- Immediate publication on acceptance

- Inclusion in PubMed, CAS, Scopus and Google Scholar

- Research which is freely available for redistribution

Submit your manuscript at 